\title{
International standards application in machine building
}

\author{
Maria Ostapenko, Vladlena Nazarova*, and Natalia Voronova \\ Industrial university of Tyumen, Tyumen, Russia
}

\begin{abstract}
Machine building is one of the leading industries. A modern man cannot exist without mechanical production. Nevertheless, the volume of manufactured products is large, and each part of it requires normative and technical documentation. Standards are introduced at enterprises to meet the demand of consumers in mechanical production. The standards also allow mechanical production to compete in domestic and foreign marketplaces. This paper analyzes the machine-building industry. The features and leading centres of machine-building placement are given. The main standardization problem in the field of machine-building was also considered, and the issue of harmonization of national and international standards for mechanical production was touched. The application of standards at machine-building enterprises was analyzed.
\end{abstract}

\section{Intriduction}

Machine building is one of the world's leading industries. Mechanical engineering products account for about $35 \%$ of the world's industrial products [1].

Many machine-building enterprises use cutting tools with specific cutting edges. The characteristics tools and their applications must be known in order to make decisions and perform production operations.

The mechanical engineering industry is a rather multidimensional and multifaceted process in terms of a practice-oriented approach and the implementation of the holistic concept of an industrial complex [2].

The main goal of this industry is to meet consumer demand for technical installation, equipment and machines, as well as to provide new products to the domestic and foreign marketplaces. It produces machines, tools, equipment, robots, and production facilities, and thus supplies the process technology for virtually all other industries [3].

Due to rapid progress, the industrial composition of machine building is subject to regular changes. Currently, the machine-building industry includes more than 70 subindustries and manufactures. From all the variety of subindustries of machine-building, there are:

heavy vehicle construction;

general engineering (be exclusive of light vehicle construction, and foodservice industry); secondary machine-building;

precision machine-building;

\footnotetext{
*Corresponding author: nazarova_vy@mail.ru
} 
metal billet and metal product manufacturing.

All of the above subindustries have their distinctive features. However, they also highlight the standard features presented in figure 1, which are typical for the entire machine-building industry.

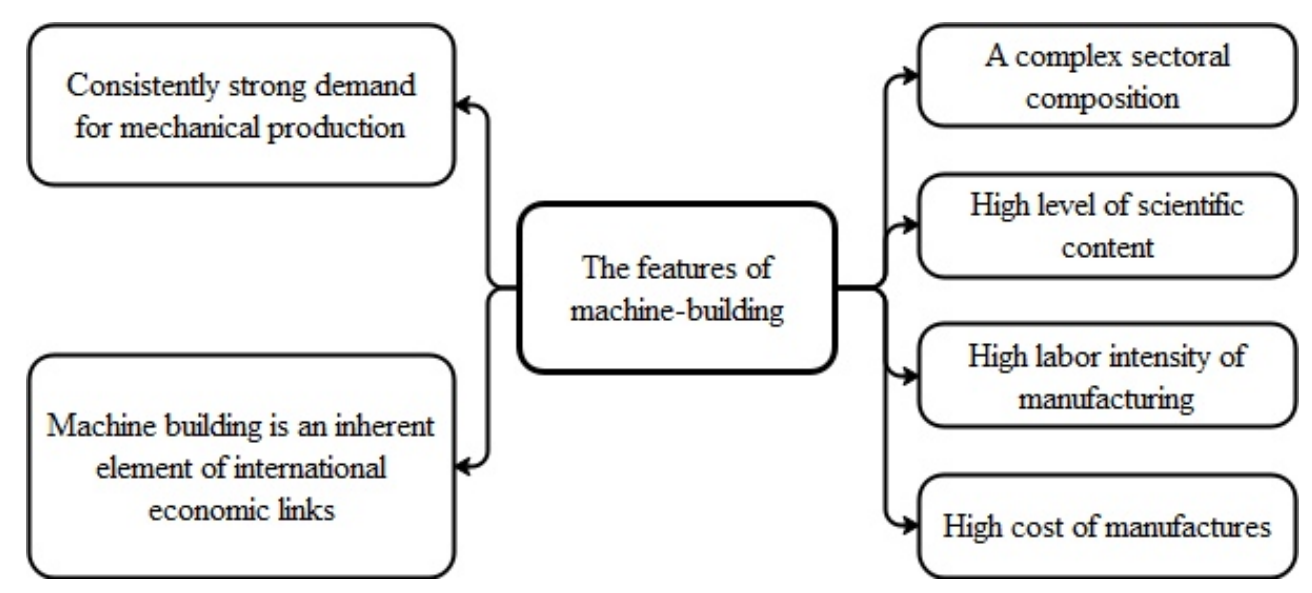

Fig. 1. The features of machine-building.

The machine-building industry is advanced and continuously developing. It always implements most of the research and development achievements.

Gratitude to technological development and consumer demand, the range of machinebuilding products is expanding and improving. An active increase in machine-building production requires qualified specialists and contributes to creative work centres.

It should be noted that the persistent demand for machine-building products has led to the fact that this industry accounts for about $1 / 3$ of the cost of all global industrial products.

\section{Russian machine-building centres}

Every large (and sometimes medium) city in the country has a factory or other machinebuilding enterprise: general, secondary or massive. Figure 2 shows the shares of machinebuilding centres located in the Federal districts of Russia. 


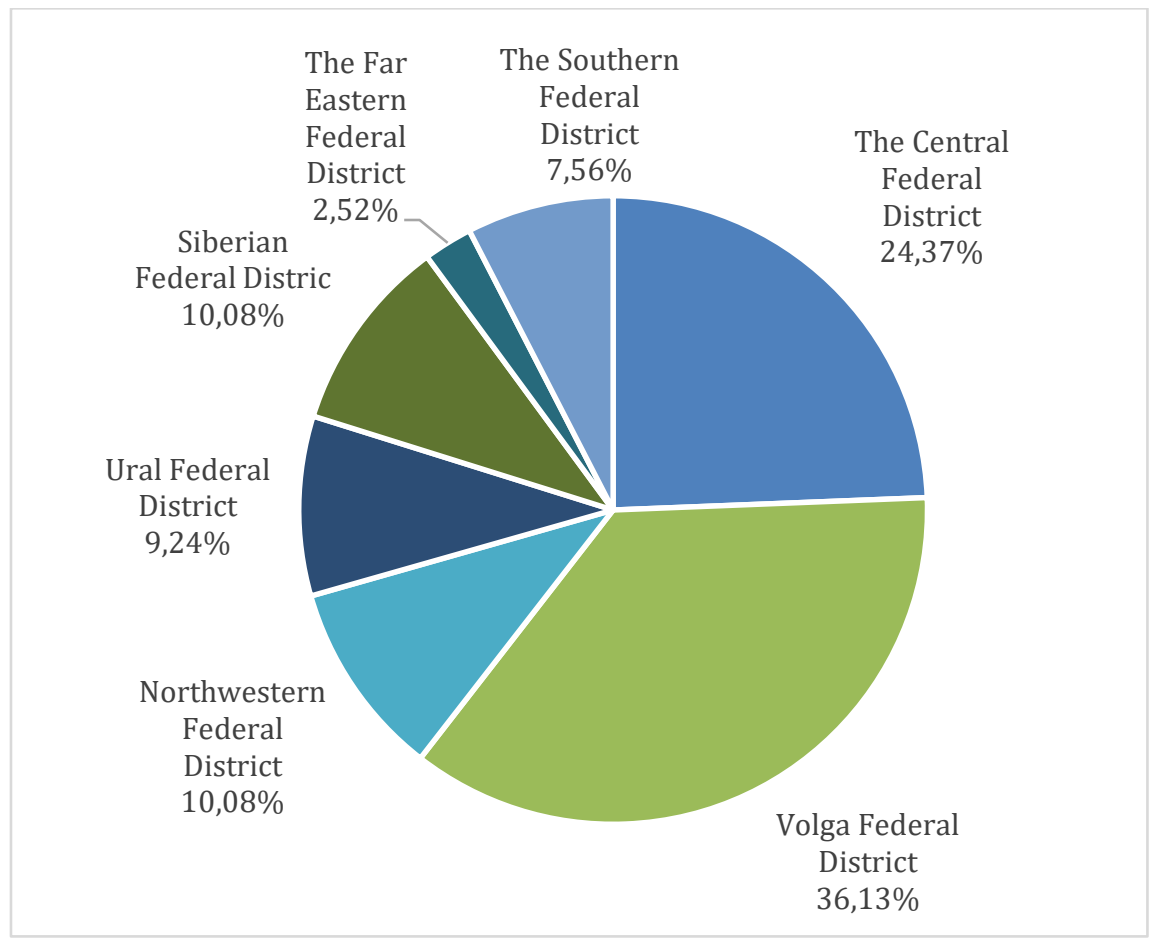

Fig. 2. The shares of machine-building centres located in the Federal districts of Russia

As can be seen from figure 2, a large number of machine-building enterprises are concentrated in the Volga Federal district (36.13\%) and the Central Federal district (24.37\%).

Many factors, among which justify the placement of the machine-building industry in these Federal districts:

They developed transportation infrastructure. Finished products, as well as the necessary components for their manufacture, require long-distance transportation. Due to this, most of the manufacturing facilities are located in places where major traffic arteries are developed.

Availability of scientific centres. Currently, science is one of the essential components of any industry. That is why machine-building enterprises are mainly located in areas where there are scientific centres and a highly developed intellectual base.

Availability of consumers. Products of the machine-building industry are diverse (from large aircraft to watches). Therefore, the location of enterprises in this industry depends on consumers.

They have a skilled labour force and engineering skills availability.

\section{Placement of machine-building industries}

There are four central machine-building regions in the production of machinery and equipment. Among them, North America takes the top place in terms of productivity levels $(30 \%)$. The second region is Western, Central and Eastern Europe, where about $30 \%$ of the world's machine-building products are manufactured. The third region, which includes the countries of East and South-East Asia, accounts for about $25 \%$ of the world's mechanical production. Russia and the former Soviet republics form the fourth region of the world machine-building industry. The CIS belongs to a group of countries with a full range of machine-building production. 


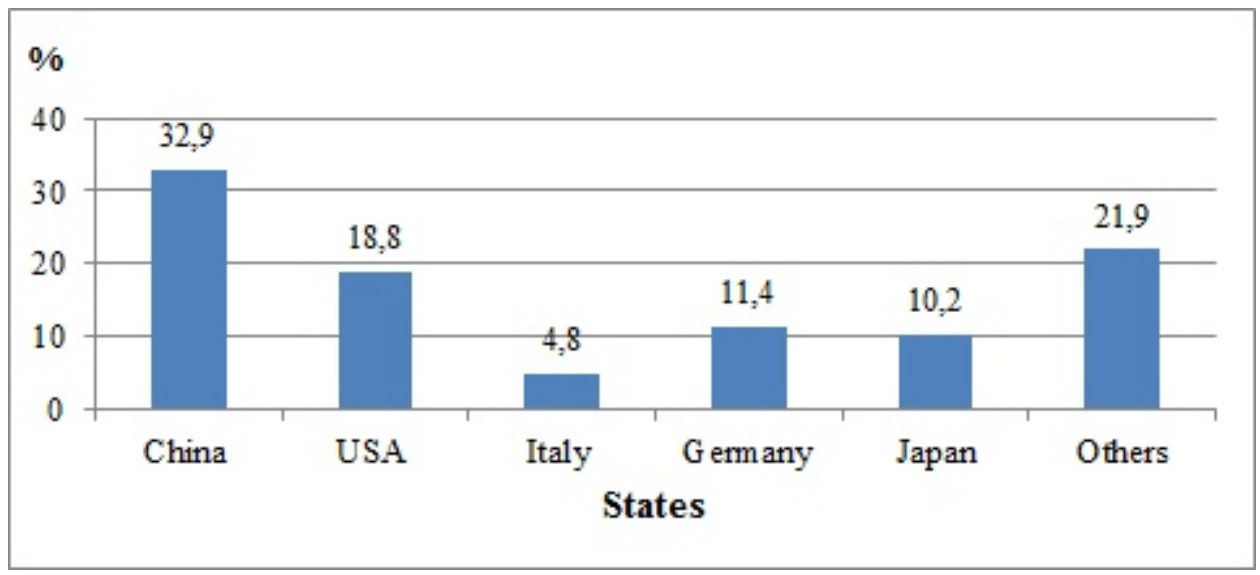

Fig. 3. Percentage distribution of machinery production in the world

Figure 3 shows that the dominant share of machine building is accounted for by countries such as China, the United States, Germany, and Japan. The remaining $21.9 \%$ is accounted for by emerging countries such as Switzerland, the Netherlands, Sweden and others.

Machine-building has also advanced significantly in developing countries. In advanced countries, machine-building is based on a high level of research and development, as well as a skilled labour force. Such industries are mainly focused on the production of technically complex and high-quality products. Engineering in developing countries is based on the cheapness of local labour. They specialize, as a rule, in the production of mass, labourintensive, but technically simple low-quality types of products. Among the enterprises here are many assembly plants that receive a set of machines in laid-up form from industrialized countries. Few developing countries have a modern machine-building manufacturing facility, mostly new industrial ones-South Korea, Hong Kong, Taiwan, Singapore, India, Turkey, Brazil, Argentina, and Mexico.

\section{The standards application at machine-building manufacturers}

Quality of products is one of the factors determining customer satisfaction and profit for the company [4]. Standardization is the most critical activity in the implementation of quality control for manufactured products.

Reference documentation sets requirements for the quality specifications of manufactured products, standards, and regulates the rules for the work and operation performance of the entire enterprise [5]. Russia is a leader in the global society in terms of scientific treatizes and standardization, but it lags in terms of the quality of its products for General machinebuilding applications. It is impossible to provide the industrial activity of the country without the usage of equipment and tools of home manufacture under current conditions of penalties and import substitution [6]. The quality problems are due to the machine train wear-and-tear by 80 per cent and the lack of funds for its renewal.

By global changes, the activities of the international organization for standardization ISO are aimed at solving several problems related to sustainable development [7]. Russia is an active member of almost all ISO technical committees on mechanical production. Harmonization of domestic and international standards is among the priority areas of Federal agency for technical regulation and metrology (Rostekhregulirovaniye). Federal statutory and regulatory enactments fix the developed and implemented national standards [8].

Recently, there are many new methods for optimizing machining in machine building, which are used in individual manufacturers. These methods are using because there is no 
standardization in this sphere. These methods are not standard, which causes significant damage to manurers in the machine-building industry.

The Fund of state standards in machine building contains all types of standards: from standards for parameters, dimensions, technical requirements for specific types of products to terminological ones. Currently, manufacturers, including those in the machine-building industry, use a variety of standards. Most companies implement a quality management system that confirms that their products meet the challenges of consumers, as well as allows them to compete in the international marketplace.

The main standards applied at Russian machine-building enterprises are:

- ISO 9001:2015 Quality management systems - Fundamentals and vocabulary. This standard contains the basic concepts, principles and notation of quality management systems, as well as the basis for other standards for quality management systems. The standard applies to all organizations, regardless of size, complication, or business model. The standard purpose is to increase the organization's awareness of its obligations and commitment to meet the needs and expectations of consumers and stakeholders, as well as to achieve satisfaction with its products and services. The Russian official translated version of this standard is GOST R ISO 9001-2015 Quality management systems. Fundamentals and vocabulary.

- ISO 14001:2015 Environmental management systems - Requirements with guidance for use. The purpose of this standard is to offer organizations an approach to environmental protections responds to changing bioenvironmental conditions in balance with socio-economic needs. It elucidates the requirements that enable the organization to achieve the intended results that it has set for its environmental management system. The Russian equivalent of this standard is GOST R ISO 14001-2016 environmental management systems. Requirements with guidance for use.

- ISO 45001: 2018 Occupational health and safety management systems Requirements with guidance for use. This standard is intended to prevent work-related incidents and occupational diseases, as well as to ensure safe and healthy workplaces. The Russian equivalent of this standard is GOST R ISO 45001-2020 Occupational health and safety management systems. Requirements with guidance for use. This standard will inure in 2021.

- ISO 31000: 2018 Risk management - Guidelines. This standard sets out several principles that must be followed in order for risk management to be effective. This standard recommends that organizations develop, implement, and continually improve the structure and process of risk management that will contribute to the value of organizations. The Russian equivalent of this standard is GOST R ISO 31000-2019 "Risk management. The principles and guidelines."

- $\quad$ ISO 6929: 2013 Steel products - Vocabulary. This international standard defines terms for steel products according to their: a) stage of manufacture, b) shape and dimensions, and c) appearance. This standard has analogues: European standard: EN 10079:2007 Definition of steel products; National STANDARD of the RUSSIAN FEDERATION GOST R 58765-2019 Steel and alloy metal products. Terms and definitions.

- ISO 230-1: 2012 Test code for machine tools - Part 1: Geometric accuracy of machines operating under no-load or quasi-static conditions. This standard applies to fixed machine tools with mechanical drive used for machining metal, wood and other materials by the removal of chips or swarf material or by plastic deformation. National standard GOST R ISO 230-1-2010 "Test code for machine tools. Part 1. Geometric accuracy of machines operating under no-load or finishing conditions." identical to the international standard mentioned above.

- ISO/TS 13399-100:2008 Cutting tool data representation and exchange - Part 100: Definitions, principles and methods for reference dictionaries. Several parameters define 
each tool. The standard provides information in a neutral format that does not depend on a particular system or manufacturer. In Russia, this international standard is identical to the national standard of the Russian Federation GOST R 55341-2012 Cutting tool data representation and exchange.

The analysis of the application of standards by enterprises, both international and their official Russian counterparts, was treated. Figure 4 shows a diagram based on the analysis of the application of standards by enterprises.

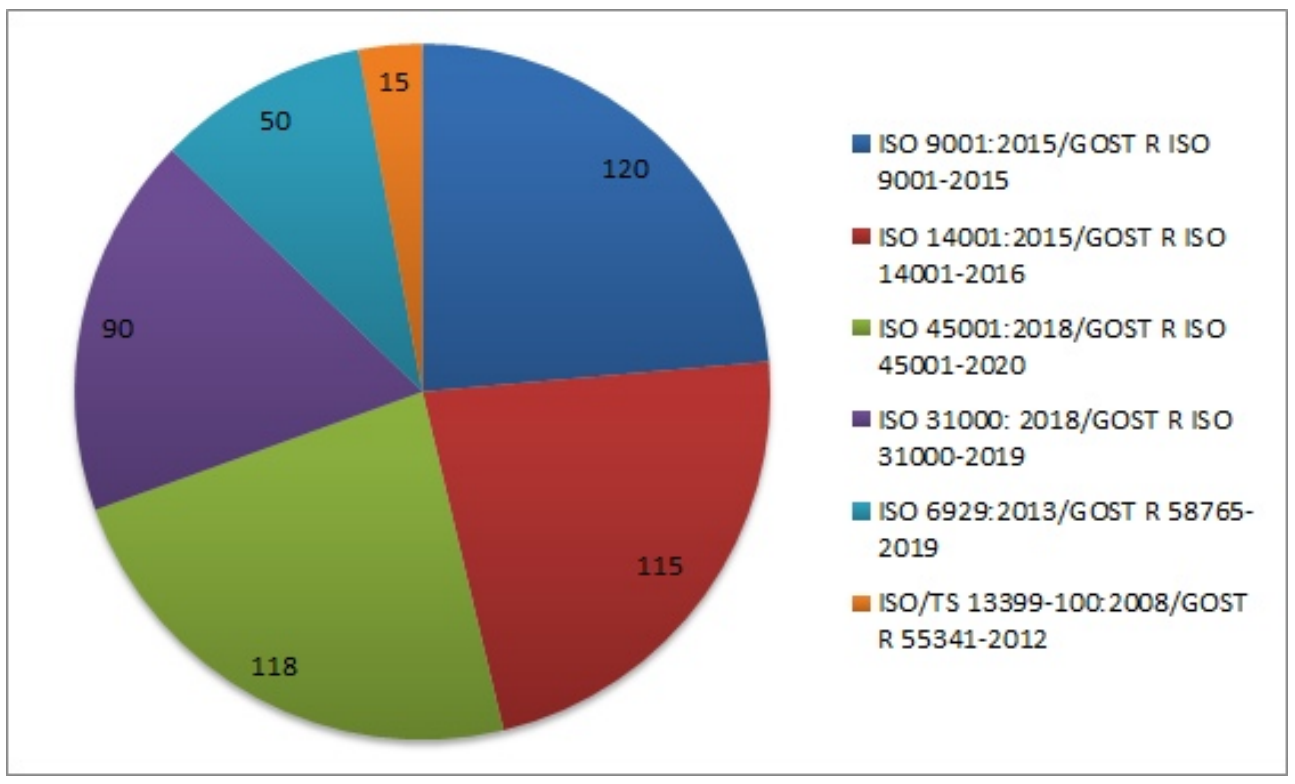

Fig. 4. The application of standards by enterprises.

As can be seen from figure 4, most enterprises use both international standards and their official Russian substitutes. However, the ISO/TS 13399-100:2008 Cutting tool data representation and exchange - Part 100: Definitions, principles and methods for reference dictionaries and its official Russian substitute GOST R 55341-2012Cutting tool data representation and exchange are used by enterprises much less. It is connected with the ignorance of enterprises about this standard.

\section{Conclusion}

As a result of the study, it was identified that Russian machine-building enterprises actively use both international standards and their official translated versions. A standard that is not widely used in enterprises was also revealed.

Thus, the application of standards is of particular importance at present. Production volume in the sphere of machine building is increasing, and young staff coming to research agencies, design and technological organizations and factories are not familiar with the existing forms of reference documentation. The implementation of standards at enterprises, as experience shows, greatly facilitates the development of the enterprise itself at the international level. 


\section{References}

1. A. Tulemetova, N. Janakova, Economics: strategy and practice, The analysis of top trends of development of mechanical engineering in the world and in Kazakhstan, v. 14(3), pp.99-112 (2019)

2. M.O. Iskoskov, E. Kargina, Y. Klochkov, Amity International Conference on Artificial Intelligence (AICAI), Innovative Model of the Organization of a Marketing System at Engineering Enterprises (2019)

3. I Liefner, G Zeng, China as an Innovation Nation, China's Mechanical Engineering Industry: Offering the Potential for Indigenous Innovation?, v.1, pp. 98-132 (2016)

4. E. Kardas, Production engineering archives, The assessment of quality of products using selected quality instruments, 10, pp. 5-8 (2016)

5. V. Krikovtsev, T. Petrova, "Izvestiya MGTU "MAMI", 2 (1 (19)), pp. 84-88 (2014)

6. E. Artamonov, A. Tveryakov, A. Shtin, MATEC 224, Determination of maximum working capacity of retrofittable cutters on the basis of physical-mechanical features of tool hard alloys, 01046 (2018)

7. A. Ionova, Trade Policy, Implementation of Sustainable Development Standards as a Way to Improve Competitiveness of a Company 3(7), pp.138-149 (2016)

8. D. Vasilega, N. Nikolayeva, Improving the management of industrial enterprises in the context of innovative development, Problems of standardization in the Russian Federation: theoretical and economic aspects, 2, pp. 97-102 (2017) 